\title{
A távmunka területfejlesztési aspektusai
}

\section{Regional development aspects of teleworking}

\author{
FORGÁCS TAMÁS
}

KULCSSZAVAK: távmunka, távmunkaház, vidéki foglalkoztatás, területfejlesztés, telephelyválasztás

ABSZTRAKT: A mezőgazdaság és az ipar foglalkoztatási lehetőségei napjainkra Európa-szerte drasztikusan lecsökkentek, így a foglalkoztatottak nagy része ma már a tercier szektorban dolgozik. Ez a folyamat a munkalehetőségeket elsősorban a városok köré centralizálja, a vidéki települések foglalkoztatási lehetőségei pedig erősen beszűkülnek. Az információs technológia terjedése és a globalizáció azonban átalakítja a gazdaság térszerkezetét, és megreformálja a foglalkoztatást is újszerǔ munkaszervezési módok elterjedésével. Ez az átalakulás azonban új eszközöket nyújthat a területfejlesztők számára is.

A távmunka például rugalmas és költséghatékony foglalkoztatási megoldást jelenthet a munkáltatónak, és egyúttal lehetőséget az innovációra képes vidéki régióknak. A távmunkaházak segítségével munkavégzési tereket hozhatnak létre a foglalkoztatási problémákkal küzdő térségek. Az iroda- és bérköltség által realizálható költségcsökkentés vonzó lehet ugyanis a nagyszámú adminisztratív munkaerő† foglalkoztató vállalatok számára. A gombamód elszaporodó szolgáltatóközpontok, telefonos ügyfélszolgálatot és értékesítést nyújtó szolgáltatók, a kötvények és kárakták rögzítését végző biztosítók, a könyvelőirodák munkavállalói mind-mind könnyen betanítható és számítógépen végezhető tevékenységeket végeznek. A területi különbségekből realizálható mintegy 30-40\%-os költségcsökkentés jelentős érv lehet ezen vállalatok számára, hogy megfontolják a vidéki térségekben kialakítandó távmunkaházakban való foglalkoztatás lehetőségét. Az egyes funkciók kihelyezése más - olcsóbb fenntartási költségeket biztosító - országokba már eddig is gyakorlat volt, így a távoli munkavégzést lehetővé tevő munkaszervezési alapok már ismertek a nemzetközi vállalatok számára. Ehhez hasonló, de kisebb léptékú átszervezéssel, a meglevő fővárosi adminisztrációs osztályokat kissé tovább darabolva, viszonylag egyszerǔen válhał valósággá hazánkban is a betanítható, számítógépen végzett, adminisztrativ munkák vidéki térségekbe helyezése. Ennek a lehetőségnek a szakmai és politikai koordinálásával munka és ezáltal munkabér "irányítható" a kivánt régiókba, ezzel fellendítve a helyi gazdaság fejlődését.

KEYWORDS: telework, telework centers, rural employment, regional development, location

ABSTRACT: Employment opportunities in agriculture and in the industrial sector have dramatically decreased across Europe, shifting employment towards the service sector. This process concentrates employment in and around towns and bigger cities. As a consequence, employment opportunities in rural areas have become extremely limited. Information technology and globalisation transform the spatial

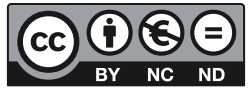


structure of the economy. These changes may offer innovative working forms which, in turn, could provide new tools for spatial development experts.

Teleworking, for example, offers a flexible and cost-effective solution for employers, and at the same time creates an opportunity for economic growth in innovative rural regions. By setting up telework centres, underdeveloped regions are able to create jobs, even where individual household cannot be provided with the required equipment and infrastructure. The cost reduction in office rental and salaries could be attractive for organisations employing a large number of administrative staff. The employees of the rapidly increasing number of shared service centres, call centres, telemarketing companies, insurance companies recording bonds and accident files, accountant offices are all working fully on computers, performing tasks within easy-to-learn workflows. The prospect of cost reductions of 30-40\% which can be realised on the regional wage-level differences should be a convincing argument for such companies to consider letting employees work from telework centres established in rural regions.

Outplacement of functions into countries offering cheaper overhead costs is a known practice already for international companies, therefore the know-how of organising work from remote locations is already available. In a similar vein, but on a smaller scale, splitting present administrative departments into smaller units could enable easy-to-learn, computer-operated administrative jobs to be outplaced to rural regions. With professional and political coordination of this process, employment opportunities and thus income could be redirected to underdeveloped regions, fostering local economies.

A területfejlesztés olyan döntések és tevékenységek összessége, amelyek közvetlenül a társadalom és a gazdaság térbeli szerkezetének bizonyos célok érdekében való megváltoztatására irányulnak. A területfejlesztés megvalósítható konkrét objektumok létesítésével, vagy az intézmények, vállalkozások és emberek tevékenységének befolyásolásával.

A regionális gazdasági fejlesztés elméletének kiindulópontja a keynes-i multiplikátor-hatás, amely azt fejezi ki, hogy a külső beruházásnak gazdaságélénkítő, továbbgyürüző szerepe van. Perroux az úgynevezett növekedési pólusok és növekedési ciklusok elméletében kimondja, hogy az egyes ágazatok fejlődése más iparágak fejlődéséhez ad impulzust. Tehát, ha egy régió valamely iparágában beruházást végeznek, annak hatása lehet más iparágak fejlödésére is (Illés 2007, Hrubi 2005). Ezt az elméletet a foglalkoztatás oldaláról megközelítve láthatjuk, hogy pusztán a munkabéreknek a térségben való elköltésén keresztül a beruházás közvetett hatással lehet a helyi szolgáltatók és kereskedők gazdasági fellendülésére is.

A területi munkamegosztás elmélete jelentős részben a telephelyelmélet tételein alapul. Ricardo azt fogalmazta meg, hogy két régió között akkor érdemes valamely termelésre szakosodni és saját szükségleten felül termelt árukat kereskedelem keretében kicserélni, ha az egyes termékek termelékenységi arányai a régiókban különbözők, és minden régió arra szakosodik, amiben relatív előnye nagyobb, vagy relatív hátránya más termelőágazatokhoz képest kisebb (Hrubi 2005). A saját szükségleten felül előállított termékek kereskedelmét a foglalkoztatáspolitika szempontjából nézve a termelésben részt vevő 
munkaerő-tényezők rendelkezésre állásaként is értelmezhetjük. Ha tehát egy adott régiónak munkaerő-tényezői meghaladják a helyben lévő vállalatok igényeit, akkor munkaerő-felesleg, munkanélküliség jelenik meg. Amennyiben ez a munkaerő „eladható”, ha ilyen képességekkel más régióban müködő vállalatok számára is alkalmas lehet, s rendelkezésre állását kedvezőbb feltételekkel tudja a vállalatok számára elérhetővé tenni, akkor komparatív előnyei megnőnek más régiókhoz képest. (Ezt nevezhetjük a globális versenyképesség javulásának is; mondandóm szempontjából csak terminológiai különbségről van szó.) A távmunka itt az „eladást” támogathatja, hisz a lokális munkaerő már nem csupán a helyben letelepült vállalatok számára vehető igénybe. A termelők és szolgáltatók ugyanis nemcsak a költségek csökkentésével, hanem területileg differenciált ár- és piacpolitikájukkal is képesek nyereségüket növelni. A gazdasági növekedés során létrejönnek perrouxi értelemben vett „növekedési pólusok” és „növekedési centrumok”, amelyek tevékenysége a gazdasági kapcsolatok révén pozitív vagy negatív hatást gyakorol környezetükre. Ebben a térbeli koncentrációs folyamatban megváltozik a hagyományosan vizsgált „klasszikus” telepítési tényezők súlya és jelentősége. Mellettük más tényezők (a munkaerő rendelkezésre állása, a támogatások, az infrastruktúra költsége, a nem áruszállításban megtestesülő együttműködés stb.) nagyobb fontosságra tesznek szert, amit a régiók kedvezően ki tudnak használni, mint azt majd látni fogjuk. Ilyen növekedési gócok, központok létrejöttét támogathatják a távmunkaházak, amelyek - megfelelő tervezés és helyszín kiválasztása esetén - a térség szabad munkaerő-kapacitását megfelelő átképzések révén „eladhatóvá” tehetik, így komparatív előnyhöz (globális versenyképességhez) juttatva a térséget.

A tercier gazdaság egyre nagyobb teret hódít, és a munkavégzés nagy része ma már számítógépen történik. A szolgáltatótevékenységeket kiszolgáló jelentős méretü háttérosztályok (back office) elvileg a cégközponttól függetlenül bárhová telepíthetők, nem kötik őket a telephelyválasztással kapcsolatos hagyományos szempontok, amelyek egyes régiókat a hagyományos feldolgozóipari tevékenységek számára kevésbé tettek vonzóvá. Mivel a munkaerő alkalmazásának feltétele a munkavégzéshez szükséges ismeret birtoklása, valamint költsége, így az alacsonyabb átlagkeresetet biztosító régiók versenyképessége a munkaerő képzése révén globális szinten is jelentős lehet - komparatív előnyeik kihasználása hozzásegítheti a régiókat, hogy növekedési centrummá váljanak. Ez a folyamat lehet alulról szerveződő és felülről szerveződő. Ha egy régió felismeri ezt a lehetőséget, akkor a homogenitáson és nodalitáson alapú térségek összefogásával alulról szerveződve is komparatív gazdasági előnyöket nyújtó működési környezetet alakíthat ki az egyes munkafeladataikat távmunkában az adott térségbe szervező vállalkozásoknak ezáltal a régióba beáramló béreken keresztül gazdasági fellendülést indukálhat (push-hatás). Ennek gyakorlati megvalósulása lehet például egy kistérségi távmunka-stratégia elkészítése (Forgács 2008b). Felülről szerveződő régiók is 
létrejöhetnek, ha a tervezett növekedési centrumokat központilag kijelölik, és tudatos fejlesztésük elindul (pull-hatás). Ilyen jellegű fejlesztés eszköze lehet a területi alapon meghatározott támogatások nyújtása, például távmunkaházak létrehozására (Forgács 2008a). Tehát mindkét esetben a megfelelő igényfelmérés alapján nyújtott képzéssel, infrastruktúra létesítésével és támogatás nyújtásával foglalkoztatás vonzható a térségbe a távmunka révén.

„A gazdasági versenyképességet meghatározó társadalmi-gazdasági faktorok között döntőek a humán tényezők. A sikeres térségekben a munkaerő tudásbázisa magas, rugalmasan tud alkalmazkodni a változásokhoz. A kilencvenes évek magyarországi területi folyamatai is azt támasztják alá, hogy a társadalmi-gazdasági változás adta lehetőségeket azok a térségek tudták a legjobban kihasználni, amelyek nemcsak kedvező földrajzi helyzetűek voltak, de rendelkeztek megfelelő humán potenciállal is. A jövedelmikereseti viszonyok két oldalról hatnak a gazdaság térszerkezetére, miközben ki is fejezik annak teljesítőképességét. Az átlagos jövedelemnagyság, a térségben lévő összes jövedelem a belső fogyasztópiac nagyságát, minőségét jelzi. A munkaerő képzettségén túl a telephelyválasztás lényeges szempontja a munkaerő ára, amit pedig lehetőleg azonos ágazatban, azonos nemü, foglalkozási jellegü csoportok átlagbérén keresztül vizsgálhatunk" (VÁTI 2003, 30-31.). Magyarországon a fővároson kívül mintegy 30\%-kal alacsonyabbak az átlagbérek, így a befektetők döntéseit befolyásolhatják az országon belüli bérkülönbségek, amelyek azonos, a munkavégzéshez elegendő mértékű munkaerő-képzettséget biztosító térségek között is fennállnak. Ez versenyelőnyként jelentkezhet az alacsonyabb bérű, de megfelelő alapképzésben részesült munkaerővel rendelkező térségek számára.

Hrubi írja a szolgáltatásoknak a regionális fejlesztésben betöltött szerepéről: „A kínálati oldal támogatása olyan intézkedéseket tartalmazhat, mint például egy átfogó emberierőforrás-politika (a munkaerő-állomány képzése), vagy közvetlenül az üzleti szolgáltatások alapításának ösztönzése. Elméletileg az elegendő számban rendelkezésre álló szakképzett munkaerő révén egy régió nagyobb eséllyel tud fejlett üzleti szolgáltatásokat és egyéb tudásintenzív vállalkozásokat vonzani (vagy tudja létrejöttüket helyben inspirálni). A képzési és oktatási kezdeményezések mellett az emberierőforrás-politika törekedhet egy adott város vagy terület társadalmi-kulturális-politikai környezetének a fejlesztésére is, hogy vonzóbbá varázsolja azt a magasan képzett szakemberek számára. Ugyanígy, a fejlett üzleti szolgáltatások elégséges tömege révén egy régió képes lehet kiegészítő (azaz nem szolgáltató) gazdasági tevékenységek számára vonzóbb telephellyé válni" (Hrubi 2004, 110.). A távmunka ezt a lehetőséget tovább bővíti azzal, hogy nem kell a teljes szolgáltatást (pl. a cégközpontot, telephelyet) egy adott régióba vonzani, a központ maradhat akár egy nagyvárosban. A cég csupán a munkaerő egy részét foglalkoztatja különböző helyekről a távmunka révén, aszerint, hogy hol találhatók ár-érték arányban a legmegfelelőbb szakemberek. Ez a „hely- 
függetlenség" teszi a távmunkát egyedülállóvá: nincs más olyan foglalkoztatási mód, amely ekkora szabadságot tudna biztosítani a munkaerő megválasztásában. Olyan munkahelyeken, ahol a munkavégzés nem kötődik egyértelműen meghatározott helyhez, egyre inkább a távmunka válhat a szervezet menedzselésének hatékony eszközévé. „Az új foglalkoztatási formákkal nemcsak állandó költségeit csökkentheti a vállalat, hanem jelentősen növelheti humánerőforrásainak színvonalát és elkötelezettségét is, hiszen a szokásosnál szélesebb körből válogathatja ki alkalmazottait, és ráfordítás nélkül növelheti érdekeltségüket. Nem hanyagolhatók el a társadalmi szintű előnyök sem a lakóingatlanok jobb hasznosításától a gyerekes anyák mint munkavállalók karrierproblémáinak és szakmai képzettségének szinten tartásig" (Hoványi 2002, 259.).

A távmunkaházakban rejlő területfejlesztési lehetőségek a vidékfejlesztés, vidéki foglalkoztatás szempontjából is hangsúlyosak lehetnek (Forgács 2006). A vidékfejlesztés elsődleges fókuszát a vidéki területek, települések és lakosságuk képezi. A tőle származó, „alulról jövő” kezdeményezések célja az emberi tevékenység és a természet fenntartható szimbiózisának megteremtése. A mezőgazdasági foglalkoztatottak arányának jelentős csökkenése azonban már a 80-as évekre jelentős munkanélküliséget generált a vidéki területeken. Az alternatív foglalkoztatási lehetőségek a mai napig nem képesek megoldani ezt a problémát, és a megélhetés biztosításának hiányában a vidéki települések elnéptelenednek. Képzéssel azonban a vidéki munkanélküliek egy része felkészíthető néhány alapvető infokommunikációs eszközökön végzett tevékenység ellátására (pl. call-center, adatrögzítés), ezáltal a távmunka révén egyes vidéki csoportok foglalkoztatása ismét megoldhatóvá válhat. Az infokommunikációs elérhetőség fejlesztése hozzájárulhat a lakóhely- és munkahelyfunkció szétválásához, amelyet a szuburbanizációs folyamatok is támogathatnak. Érdemes azonban megkülönböztetni a szuburbán zónába telepített szolgáltatói/háttérirodai funkciókat a tényleges vidékfejlesztésben használt távmunkaházak szerepétől. A két - formailag hasonló - munkacentrum más funkciót tölt be, már csak helyzeténél fogva is, s más területfejlesztési hatásrendszer várható tőle. Az előbbi alkalmas a korábbi monocentrikus városrégió fejlődésének policentrikus irányba történő elmozdítására, anélkül, hogy a régiós, országos nagystruktúrákat érdemben decentralizálná, sőt tartósítja a területi egyenlőtlenségeket. Az utóbbi viszont érdemi dekoncentrációs hatást eredményezhet, legalábbis a munkahelyek területi megoszlásában, anélkül, hogy a gazdaság irányításán belül meglévő hatalmi viszonyokat a legcsekélyebb mértékben átalakítaná. 


\section{Távmunka és telephelyválasztás}

A gazdaság térszerkezetét nagyban meghatározzák a vállalkozások telephelyválasztási szempontjai, amelyek között mindinkább felértékelődnek a humánerőforrások mennyiségi, minőségi jellemzői. A munkavállalók „rendelkezésre állása" ugyanakkor nem minden esetben biztosított, hazánkban a munkaerő mobilitása igen alacsony, így ez az egyik leginkább térhez (lakóhelyhez) kötött termelési tényező. Ezáltal a humánerőforrás rendelkezésre állása egyre inkább meghatározó szerepet játszik a gazdaság szereplőinek térbeli településében, ily módon a gazdasági térszerkezet formálásában.

„A globális gazdasági rendszerek terjedése a kilencvenes évek elején érte el hazánkat, ami természetesen együtt járt a gazdasági, politikai és társadalmi környezet rendszerváltozás általi megnyitásával. A globalizáció hazai megjelenésével foglalkozó elemzések rávilágítanak arra, hogy a területi elhelyezkedés roppant rugalmassá vált, ennek megfelelően a településeknek versenyezniük kell a telephelyért, s ebben a versenyben fó tényezővé vált a tudás és a hozzá kötődő szolgáltatások egész sorozata. Emellett a helyi adottságok, a lokális erőforrások felértékelődnek, amelyek számos gazdasági (pl. a munkaerő költsége, az infrastruktúra rendelkezésre állása, a helyi innovációs környezet) és nem gazdasági (pl. közösségi kapcsolatok, támogatások) tényezőben nyilvánulnak meg. Megszűnnek a homogén régiók, térhálózatok alakulnak ki, s ezekben a hálózatokban kell a településeknek, térségeknek a helyzetüket stabilizálni, illetve a be nem kapcsolódott egységeket - döntően a központi regionális politika segítségével - felfüzni. Mindez a versenyképesség javításában nyilvánul meg" (VÁTI 2003, 6.). Ha tehát egy régió megfelelő stratégia mentén képes olyan müködési környezetet kialakítani, amely a vállalkozások számára gazdasági előnnyel jár, akkor a vállalkozások beruházásokat indíthatnak, foglalkoztatást hozhatnak létre. A távmunka lehetőséget ad a termelőeszközök elválasztására az érékesítési és termelési központtól. Emiatt érdemes áttekinteni a vállalatok telephely-választási szempontjait, hogy meghatározhassuk, melyek azok, amelyek fejlesztésével egy régió komparatív elönyökhöz juthat, és a távmunka révén gazdasági fejlődés indukálódhat.

A telephelyelmélet a gazdaság egységeinek térbeli elhelyezkedésével és múködésével mint általános gazdasági törvényszerűséggel foglalkozik. A telephelyelméletek a gazdaság átalakulásával folyamatosan bővültek. „Walter Isard már nemcsak a költségminimalizálást vagy nyereségmaximalizálást határozza meg a telephely-kiválasztás céljaként, hanem az összes tényező optimalizálását tartja fontosnak. Az elmélet fontos eredménye a tényezők helyettesíthetőségének és az infrastruktúra szerepének felismerése. (...) Reinmuth Jochinsen háromdimenziós infrastruktúra-elméletében (1966) az anyagi mellett a szellemi és az intézményi infrastruktúrát mint dimenziókat azonosította. lsard, Greenhut és Smith a gazdasági tevékenység térbeliségére ható va- 
lamennyi tényezővel számolt: a termelés és a fogyasztás mellett a településsel, a infrastruktúrával is foglalkozott. Az összes tényező figyelembevételével kialakított (matematikai) modell optimalizálásával próbálták a legmegfelelőbb telephelyet meghatározni. Az 1970-es évektől Stöhr, Malecki és Scott munkássága alapján a telephelyelméletek fontos komponense, hogy az infrastruktúra térben nagyjából egyenletes kiépülése után a mikroelektronikára és az informatikára alapozott innovációk és csúcstechnológiák kerülnek az előtérbe. A telepítésnél a magasan képzett, kreatív munkaerő, a települések szolgáltatásai és a környezet állapota felértékelődnek, komplex, egymástól kölcsönösen függő telepítési döntések születnek" (Ács 2005, 5-6.).

A telephelyválasztás tehát komplex döntési probléma, amely mindig különböző tényezők és szempontok kombinációit veszi alapul. Ács (2005) összefoglaló kutatása alapján főbb tényezői: természeti környezet, termelési tényezők (föld, munkaerő, tőke), kereslet, szállítás, térbeli kapcsolatok, technológia, szervezeti, politikai és társadalmi tényezők. A munkaerőnek mint termelési tényezőnek három jellemzőjét célszerü vizsgálni: típusát, mobilitását és költségét. A típusnál a nemek és a képzettség szerinti térbeli megoszlása dominál. Hazánkban különösen korlátozott a munkaerő térbeli mobilitása, ami tradicionális kulturális okokra vezethető vissza, azonban a távmunka pont erre a foglalkoztatási nehézségre adhat választ, mivel nem a megfelelő szakembereket kell egy helyre csoportosítani, hanem a munkát lehet szétosztani a megfelelő munkaerő számára. A munkaerő költségének kialakulásában döntő szerepet játszik a szakképzettség, amely alapján megoszlik az igény a speciális szakértelmet igénylő munkát ellátók, valamint az olyan érettségizett szakképzetlenek iránt, akik gyorsan betaníthatók egy-egy mechanikus részfeladat elvégzésére. Az egységnyi munkaerőköltség jobban meghatározza a termelői árat, mint az adók, vagy akár a szállítási költségek. A bérek versenyképessége azonban függ a képzettségtől, a munkaerő mobilitásától, a munkaerőpiac országos szabályozásától, a bérek régiók közötti különbségétől, a kollektív szerződések decentralizációjának kisebb vagy nagyobb fokától, a szakszervezetek tevékenységétől. Az alacsony bérköltségek miatt meglévő versenyképességi előnyök azonban további elemekkel is bővíthetők, mint például az ország egyes részeire vonatkozó adókedvezményekkel, foglalkoztatási támogatásokkal, így akár mesterségesen kedvezőbb környezetet teremtve azokban a térségekben, ahol foglalkoztatás szempontjából komparatív bérelőnyt akarunk biztosítani.

Az egyensúlyi növekedés elmélete kimondja, hogy az elmaradott területek progresszív szakosodással és a már fennálló gazdasági rendszerbe való bekapcsolódással - a komparatív gazdasági előnyök klasszikus törvénye alapján - gazdasági fejlődést érhetnek el. Az elmélet gyakorlati alkalmazását a helyi kormányzati stratégiák és döntések tehát nagyban befolyásolhatják, mert elősegíthetik a funkcionális térbeli munkamegosztást az integrált termelési folyamatok speciális szakaszainak térben való elkülönülésével (távmunka). A 
1. táblázat: A telepítési tényezők típusai

\begin{tabular}{|c|c|c|}
\hline Kemény telepítési & \multicolumn{2}{|c|}{ Puha telepitési tényezók } \\
\hline $\begin{array}{l}\text { - A beszerzési és } \\
\text { felvevőpiacokhoz } \\
\text { viszonyított fekvés } \\
\text { - Közlekedési } \\
\text { kapcsolatok (utak, } \\
\text { sínek, víz, levegő) } \\
\text { - Munkaerőpiac } \\
\text { (mennyiségi, } \\
\text { minőségi) } \\
\text { - Telephelykinálat, } \\
\text { (ipari) telephelyek } \\
\text { ára/bérleti dija } \\
\text { - Energia- és környezeti } \\
\text { - költségek } \\
\text { - Helyi adók } \\
\text { - Támogatások }\end{array}$ & $\begin{array}{l}\text { - Helyi/regionális } \\
\text { gazdasági környezet } \\
\text { - A közigazgáás } \\
\text { minősége és } \\
\text { rendelkezésre állása } \\
\text { - Város/régió image } \\
\text { - Iparági kapcsolatok, } \\
\text { kommunikációs és } \\
\text { kooperációs } \\
\text { lehetőségek } \\
\text { - Felsőoktatási } \\
\text { intézmények, kutatás } \\
\text { - A régió innovációs } \\
\text { milióje } \\
\text { - A gazdasági } \\
\text { szövetségek } \\
\text { teljesitő́képessége }\end{array}$ & $\begin{array}{l}\text { - Lakás/lakókörnyezet } \\
\text { - } \text { A környezet állapota, } \\
\text { minősége } \\
\text { - Iskolák, képzés } \\
\text { - } \text { Szociális infrastruktúra } \\
\text { - } \text { A szabadidő értéke } \\
\text { (sport, } \\
\text { - kulturális kinálat) } \\
\text { - A város és a régió } \\
\text { varázsa }\end{array}$ \\
\hline
\end{tabular}

Forrós: VÁTI 2003, 21.

telephelyválasztás ugyanis azokat a helyeket preferálja, ahol a legalacsonyabbak a munkabérek és az üzleti környezet elfogadható (Forman 2004).

Vizsgáljuk meg hát a telepítési tényezőket, hogy megállapíthassuk a távmunka munkaszervezési módjából adódó lehetséges hatásokat! A telepítési tényezőknek megkülönböztethetjük az úgynevezett „kemény” és „puha” típusait. Ezeket az 1. táblázat foglalja össze.

„A befektetők elsőként a kemény telepítési tényezőket vizsgálják meg a telephely-választási döntések során, ezen tényezők rendelkezésre állása alapfeltétele a letelepedésnek. Miután a kemény telepítési tényezőkben mutatkozó területi különbségek - többek között a telephelyek közötti fokozódó verseny hatására - eltűnnek, illetve minimálisra csökkennek, a döntésben egyre nagyobb súllyal szerepelnek a puha telepítési tényezők. Ez a tendencia Nyugat-Európában már egyértelműen kimutatható: a kemény telepítési tényezők tekintetében a földrajzi hely kivételével már szinte alig tapasztalhatóak különbségek, a vállalatok egyre inkább a puha tényezők alapján döntenek a telephelyről. Magyarországon ezzel ellentétben még jelentős területi különbségek tapasztalhatók a kemény telepítési tényezők tekintetében" (VÁTI 2003, 21.). A gazdaság térszerkezetének vizsgálata során tehát fontos szempontot jelent az, hogy a befektetők milyen tényezőket vesznek számításba telephelyválasztásuk folyamán. A kérdés tárgyalásában kitüntetett szerep jut az olyan létesítményeknek, amelyek készen kínálják a munkavégzésre alkalmas környezetet, és kedvező gazdasági környezetet biztosítanak a müködésre (pl. ipari parkok, távmunkaházak). 
Egy empirikus kutatás azt vizsgálta, hogy a külföldi beruházások mely tényezőket tartják a legfontosabbnak a telephelyválasztás során, és a munkaerő olcsósága gyakorlatilag az egyik legfontosabb tényezőnek bizonyult. Az olcsóbb átlagbérekkel rendelkező régiók természetszerűleg rendelkeznek ezzel a komparatív előnnyel, amely megfelelő helyi politikai stratégia és ösztönzés esetén realizálható előnnyé válhat. Egy másik vizsgálat a 17 közép-magyarországi ipari park tapasztalatait elemezte, és értékelte az idetelepülő vállalatok területválasztási szempontjait. A megfelelő munkaerő közelsége ezúttal is a legfontosabb kategóriába esett (VÁTI 2003, 24.).

Az eddigiek alapján megállapíthatjuk, hogy ha egy alacsonyabb átlagbérrel rendelkező régió e komparatív előnyét távmunka révén kívánja elérhetővé tenni a vállalkozások számára, akkor az alábbi fó szempontokat kell vizsgálnia:

- távmunkában ellátható tevékenységekre alkalmas, képzett munkaerő jelenléte,

- a távmunkavégzésre szükséges infrastruktúra rendelkezésre állása,

- a munkakörnyezet iparági elvárásoknak való megfelelősége,

- az infokommunikációs eszközök rendelkezésre állása, alacsony költsége,

- a munkáltató központjának néhány órán belüli elérhetőségét lehetővé tevő közlekedési infrastruktúra megléte,

- stabil és ösztönző gazdaságpolitika.

Ha egy homogén vagy nodális területi egység a fentieket biztosítani tudja, akkor a távmunka révén komparatív előnyeit elérhetővé tudja tenni a vállalatok számára, így befolyásolva telephely-választási döntéseiket. Erre a célra stratégia készíthető, amely lépésenként végigvezeti az adott régiót egy olyan folyamaton, amelynek révén foglalkoztatás jöhet létre a térségben, a beáramló bérek extern hatása révén pedig komplex gazdaságfejlesztéshez vezethet.

A távmunka szerepét tehát a telephelyválasztás szempontjából abban látom, hogy a lehetővé teszi a napjainkban egyre jobban felértékelődő munkaerő mint termelési tényező tetszőleges helyről történő alkalmazását. Ezáltal hozzájárulhat a távmunkáltató vállalatok költséghatékonyabb működéséhez és versenyelőnyének javulásához, javíthatja a távmunkásokat biztosító régiók foglalkoztatási és gazdasági mutatóit, ezzel támogatva a területfejlesztési törekvéseket.

\section{A távmunka szerepe a területfejlesztésben}

A távmunka lehetővé teszi az egyes munkafeladatok térbeli elválasztását más munkafeladatoktól. Ilyen lehet például bármilyen adatrögzítés vagy adatfeldolgozás, illetve telefonos ügyfélszolgálat vagy kereskedelem, informatikai és 
grafikai tevékenység stb. A feladatok szétválasztása pedig lehetőséget ad arra, hogy elvégzésük területileg ott történjen, ahol a gazdasági környezet erre a legalkalmasabb. A térbeli egyenlőtlenségekből adódóan (például vidéken alacsonyabbak a bér- és ingatlanköltségek) tehát a távmunkáltató vállalkozás gazdasági előnyre tehet szert azáltal, hogy az egyes betanítható munkafeladatokat a nagyvárosból kiemelve olyan vidéki helyszínen végezteti el, ahol rendelkezésre áll erre alkalmas munkaerő.

A távmunkáltatás alapfeltétele tehát a munkavégzésre alkalmas helyszín, a munkavégzésre alkalmas, képzett munkaerő, valamint a munka fogadására és továbbítására alkalmas kommunikációs háttér megléte. Ez utóbbi leggyakrabban az internet, amely ma már szinte minden településen elérhető, ha máshogy nem, akkor a mobiltelefon technológiáján keresztül (például GPRS mobilinternet). Az ezzel való ellátottság már 2006-ban 95,4\% volt (MITJ 2006.). A munkaerő és a helyszín szintén megteremthető a tevékenységek jelentős részére a legtöbb településen. A távmunka tehát út és ipar telepítése nélkül teszi lehetövé, hogy bármely településen foglalkoztatás jöjjön létre, a beáramló és a helyben maradó bérek pedig területfejlesztési hatást váltanak ki a térségben.

A távmunka típusai közül - a telephelyválasztásra gyakorolt hatása miatt - a területfejlesztési lehetőségek vizsgálatához célszerü a távmunkaházban történő foglalkoztatást választanom. Ez a foglalkoztatási mód áll ugyanis a legközelebb a hagyományos modellekhez, és a regionális fejlesztés szempontjából ez a legjobban körülhatárolható, kezelhető és mérhető egység. A távmunkaházban történő foglalkoztatás nagyrészt meghonosítja a térségben a távmunka egyéb (otthoni és mobil) formáit is.

\section{Távmunkaházak elméleti áttekintése}

Memmott már 1963-ban használta a „suburban workcenter" elnevezést, amely elképzelése szerint a vezetők részére lett volna fenntartva, hogy közelebb legyen lakóhelyükhöz, mint a vállalat. Innen el tudták volna végezni munkájukat, és munkatársaikkal is kapcsolatban lehettek volna. Healy 1968-ban a „neighborhood remote work center" kifejezést használta, olyan távmunkavégzére alkalmas helyszínt értve ezen, amely „sétatávolságra” található a munkavállalók lakóhelyétől. ő is kiemelte, hogy az ilyen központok előnyösebbek az otthoni távmunkánál, mert lehetővé teszik az eszközök megosztását, csökkentik a munkavállalók izolációját, és lehetővé teszik a közvetlen munkatársakkal való személyes kapcsolattartást. Harkness 1977-ben a Stanford Kutatóintézetében végzett számításokat, amelyek szerint a távmunkaközpontok révén 1985-re 1,4\%-kal csökkenhet az üzemanyag-fogyasztás (Bagley 1994).

A távmunkaközpontok mozgalma az 1980-as években a skandináv államokból indult. Innen terjedt el Nyugat-Európa, Ausztrália és Észak-Amerika 
országaiba, és az elmúlt években megjelent Kelet-Európában, Afrikában, Ázsiában és Latin-Amerikában. A nemzetközi és nemzeti fejlesztési ügynökségek felismerték a távmunkaközpontokban rejlő potenciált, és a világ minden táján támogatják ezeket (Latchem 2001). Az Egyesült Királyságban például minden vidékfejlesztési irodának van a távmunkaközpontok terjesztésére vonatkozó szabályzata (Crang 1999).

Az egyik legátfogóbb gyűjteményt Bagley (1994) publikálta a „Távmunkaközpontok és kapcsolódó koncepciók: Gyakorlati áttekintés" címü tanulmányában, amelyben az Egyesült Államok távmunkaközpontjait, valamint a világ más országaiban lévő modellek jellegzetességeit tanulmányozta (például Finnországban, Franciaországban, Írországban, Svájcban, Jamaikában, Japánban, az Egyesült Királyságban).

Első megközelítésben a munkáltatók száma alapján rendszerezhetjük a távmunkaközpontokat. Eszerint megkülönböztethetünk egy és több munkáltató által fenntartott távmunkaházakat, valamint nyilvánosan látogatható úgynevezett teleházakat (Bagley 1994 18, Campbell 1995). Az egy munkáltató által fenntartott házak elsősorban a nagyvállalatokra jellemzőek, amelyeknek több telephelyük van, ők képesek ugyanis gazdaságosan fenntartani hosszabb távon egy távmunkaházat (amelyet gyakran szatellitirodának nevez a szakirodalom). A több munkáltató által üzemeltett távmunkaházaknak biztosabb a fennmaradása, hisz esetükben kisebb problémát okoz, ha egy munkáltató átszervezi müködését, emiatt a nem munkáltató által kezdeményezett távmunkaházak esetében ez a preferált modell. A távmunkaházak általában zártak, oda csak a „regisztrált” munkavállalók léphetnek be munkavégzés céljából. A nyilvánosan látogatható teleházak célja egy-egy térség infokommunikációs eszközökhöz való hozzáférésének biztosítása, azaz a hangsúly itt inkább a vidéki lakosok infokommunikációs eszközhasználatba való bekapcsolásán van, nem a foglalkoztatáson.

Bagley tette a legátfogóbb kísérletet a távmunkaközpontok elnevezésének rendszerezésére, de ő is megállapítja, hogy ezek funkciójukban hasonlók, a néveltérések elsősorban kialakulásuk helye és felhasználásuk körülményei miatt jelentkeztek. Az elnevezések utalhatnak az elhelyezkedésre (például Urban Centers, Rural Work Centers), az általuk betöltött szerepre (Executive Office, Community TeleCenters), de egyes esetekben a fantázianév jogvédelmi okok miatt született (például a TeleCenter elnevezést egy kanadai tanácsadó cég levédette, így született a Telecottage). Bagley a következő típusokat különbözteti meg1: Community TeleService Centre, Creative Office, Floating Office, Non-Territorial Office, Resort Office, Satellite Office, Telecottage, Unassigned Office, Urban Telecenters, Rural Remote Work Centers, Urban Executive Office Suites. Tanulmánya összegzéseként Bagley megállapítja, hogy a legnagyobb fejlődési potenciállal a vidéki és az egy munkáltató által fenntartott távmunkaházak rendelkeznek (Bagley 1994). Hasonló konklúziót több helyen is olvashatunk a szakirodalomban (Bergum 2007, Stanek 1998). 
Dolgozatom célja szempontjából a távmunkaközpontokat csak a nyilvánosság által való hozzáférés módja alapján kívánom megkülönböztetni. Eszerint nyilvános, illetve zárt módon működő távmunkaközpontok léteznek. A Magyarországon elterjedt szóhasználatnak megfelelően tanulmányomban ezentúl a nyilvános távmunkaközpontokat teleházaknak, a zártakat távmunkaházaknak nevezem.

A nyilvános távmunkaközpontok, azaz a teleházak már létező szervezetek Magyarországon. Öndefiníciójuk szerint: „A teleház egy többfunkciós, nyitott profilú kisközösségi információs és telekommunikációs szolgáltatóközpont" (Bihari 1999, 86.). A teleházak célja elsősorban az információtechnológiai eszközökhöz való hozzáférés minél szélesebb körben való biztosítása (Bihari 1999, Bagley 1994, Campbell 1995). Dolgozatomban müködési hasonlóságukból kifolyólag ebbe a kategóriába sorolom az eMagyarország-pontokat és a nyilvánosan használható, internetelérést biztosító egyéb helyszíneket.

A definíció szerint a zárt távmunkaközpont, azaz a távmunkaház olyan irodahelyiség, ahol a munkavégzők munkafeladatokat látnak el munkáltatójuk számára, úgy, hogy a felek között munkaviszony áll fenn; továbbá a távmunkaházban korlátozott számú (egy vagy néhány) munkáltató munkavállalói dolgoznak, a munkáltatóval való kapcsolatot informatikai (például számítógép) és kommunikációs (például internet, telefon, videokonferencia) eszközökkel tartják fenn. A távmunkaházat a legtöbb esetben egy harmadik fél (például önkormányzat vagy vállalkozó) alakítja ki és tartja fenn a munkaadók egyedi elvárásai alapján, és az egyes munkahelyeket a munkaadó bérli. A távmunkaházat a helyfüggetlenség és a szervezeti felépítéstől való függetlenség különbözteti meg a telephelyektől (Mokhtarian 1991, Bagley 1994). A helyfüggetlenség azt jelenti, hogy ugyanolyan felszereltség mellett a távmunkaháznak bárhol létrehozhatónak kell lennie (ellentétben az értékesítési ponttal, amely a helyhez, azaz a piachoz kötött). A szervezeti felépítéstől való függetlenség azt jelenti, hogy a távmunkaház nem rendelkezhet saját piramishierarchiával, a munkavállalók jelentési kötelezettsége a távmunkaháztól eltérő helyen dolgozó vezető felé irányul - hacsak nem maga a vezető is a távmunkaházban dolgozik, ilyenkor viszont a vezetőnek kell hogy legyen legalább egy nem ott dolgozó beosztottja (1. ábra).

A távmunkaház tehát elsősorban abban tér el a teleházaktól, hogy az előbbi a nyilvánosság számára nem látogatható, kizárólag a távmunkaház üzemeltetőivel szerződéses kapcsolatban levő munkáltatók távmunkásai jogosultak a belépésre. Ez a különbség teszi lehetővé azt, hogy a távmunkaház munkakörnyezete a munkáltatók elóírásaihoz és szabályozásaihoz legyen igazítva. A teleházak esetében ez nem lehetséges, ugyanis a nyilvánosság kizárásával pont funkciójuk alakulna át. Ezért látom szükségesnek a fenti terminológia tisztázását, hogy egyértelműen meg tudjuk különböztetni e két müködési modellt. Magyarországon 439 nyilvánosan látogatható teleház és 
1. ábra: A hagyományos szervezet és a távmunkaház szervezeti felépítése
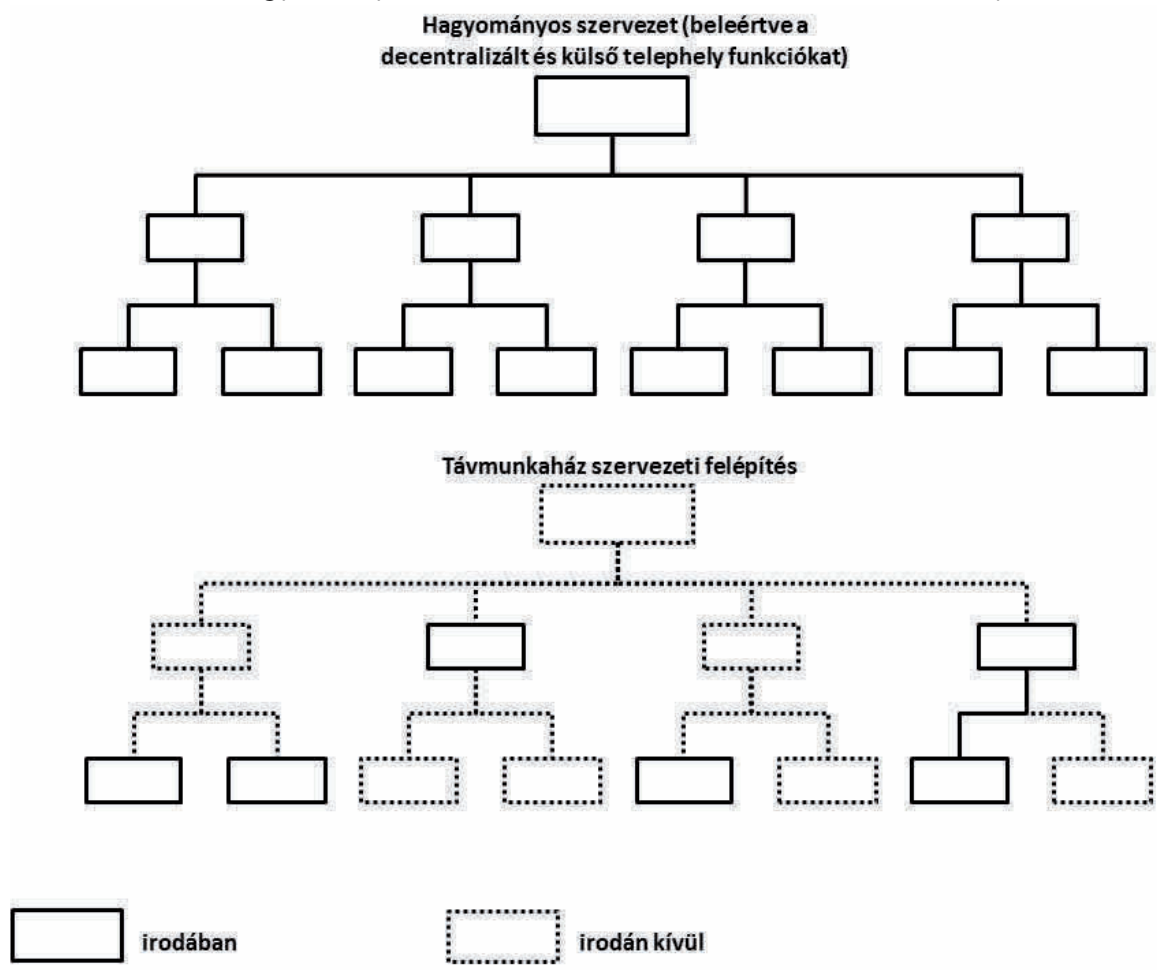

Forrás: saját szerkesztés Mokhtarian(1991) alapján.

egyetlen zártkörüen használt távmunkaház működik. Ez a távmunkaház 2007 októberében nyílt Örkényben (Forgács 2008a).

A távmunkaházat tehát a hagyományos telephelytől az különbözteti meg, hogy az előbbit általában harmadik fél üzemelteti, és az független a vállalat szervezeti felépítésétől. További különbség, hogy a távmunkaház annyiban nem helyhez kötött, hogy hasonló feltételekkel máshol is létrehozható kell, hogy legyen, nincs közvetlen kapcsolata a piaccal, ellentétben a telephelyekkel.

Az inkubátorházakban és az ipari parkokban vállalkozások üzemelnek, ellenben a távmunkaházakban munkavállalók ülnek. Ipari parkban is kialakítható távmunkaház, bár ez nem jellemző, hisz a távmunkaházat elsősorban a munkavállalók lakóhelyéhez közel telepítik, az ipari parkokat pedig a lakóhelyektől távolabb. Az inkubátorházak kisvállalatok számára biztosítanak működési lehetőséget. A definíció szerint azonban a távmunkaházban dolgozóknak kell, hogy legyen olyan munkatársa, aki fizikailag máshol helyezkedik el (2. táblázat).

A távmunka típusain belül a hagyományos foglalkoztatáshoz a távmunkaház áll legközelebb, így ennek megvalósítása lehet a legelső lépés a vállala- 
2. táblázat: A távmunkaházak megkülönböztetése más formáktól

\begin{tabular}{|c|c|c|c|c|}
\hline \multirow[b]{2}{*}{ Típus } & \multicolumn{4}{|c|}{ lgaz-e, hogy } \\
\hline & $\begin{array}{l}\text { a fenntartó a } \\
\text { munkáltató? }\end{array}$ & $\begin{array}{l}\text { az elhelyezé- } \\
\text { se kötött? }\end{array}$ & $\begin{array}{l}\text { a nyilvános- } \\
\text { ságtól elzárt? }\end{array}$ & $\begin{array}{l}\text { a szervezet } \\
\text { felépítéstől } \\
\text { független? }\end{array}$ \\
\hline Távmunkaház & nem & nem & igen & igen \\
\hline Teleház & nem & nem & nem & igen \\
\hline Telephely & igen & igen & igen & nem \\
\hline Inkubátorház & nem & részben & igen & nem \\
\hline Ipari park & nem & igen & igen & nem \\
\hline
\end{tabular}

Forrás: Saját szerkesztés.

toknál. A távmunkaház ugyanis mint szatellitiroda funkcionál, és lehetőséget biztosít a munkaadó előírásainak megfelelő munkakörnyezet kialakítására (például biztonsági követelmények, erőforrások rendelkezésre állása, logisztika). Egyes adatrögzítési és adatfeldolgozási munkakörök betanítható jellege lehetővé teszi, hogy gyakorlatilag bármely alapképzettséggel rendelkező munkavállaló képes legyen a munkafeladatok megfelelő ellátására. A távmunkaház kiküszöböli az otthoni távmunka egyes hátrányait, de elérhetővé teszi a távmunka általános előnyeit is - a távmunkaház tehát optimális megoldást nyújthat a vállalatok számára (Bagley 1994).

A távmunkaházak kezdeti időszakában még voltak olyan vélemények, hogy a távolság miatt megnövekedett kommunikációs költségek olyan jelentősek, hogy nem teszik fenntarthatóvá az üzemeltetést (Jansen 1995). Napjainkban azonban megállapítható, hogy a kommunikációs költségek gyakorlatilag távolságfüggetlenné váltak, az ország minden pontján szinte azonos áron lehet internet-hozzáférést vásárolni, továbbá a legtöbb esetben a kommunikáció forgalomfüggetlen, azaz költsége nem függ az átfutó adatok mennyiségétől. Ez a változás új korszakot nyitott a távmunkaházak számára.

Egyes országokban a távmunkaházakat ma már széles körben alkalmazzák. Az USA-ban például 1999 óta törvény² szabályozza távmunkaházak létrehozását, felépítését, sőt a ráfordítások éves minimumköltségeit is (50 000 dollárban határozza meg ügynökségenként). Washington környékén például 14 távmunkaházat üzemeltetnek, amelyeknek az elsődleges célja a nagyvárosi forgalom csökkentése, a munkavállalók lakóhelyéhez közelebbi munkavégzési terek létrehozásával (2. ábra). A WorldAtWork (2009) felmérése szerint az USA-ban 2006-ban a munkavállalók 5\%-a vette igénybe a távmunkaházak szolgáltatásait, míg 2008-ban 8\%-uk, ami lassú emelkedést mutat.

A távmunkaházak alkalmazása országonként eltérő, funkciójuk, elnevezésük és szerepük alapján igen nehéz összehasonlító elemzéseket végezni. Ennek ellenére elmondható, hogy a fejlett országok már több éve alkalmazzák ezt a foglalkoztatási módot (Obra 2002). Felismerve a távmunkaházak nyújtotta foglalkoztatási mód előnyeit, adott a lehetőség, hogy megfelelő tervezés révén Magyarország egyedi igényeihez igazodva induljon el ez a folyamat. Hiszen a nagyvárosoktól való távolság jelentősen alacsonyabb múködési költ- 
2. ábra: Washington környéki távmunkaházak

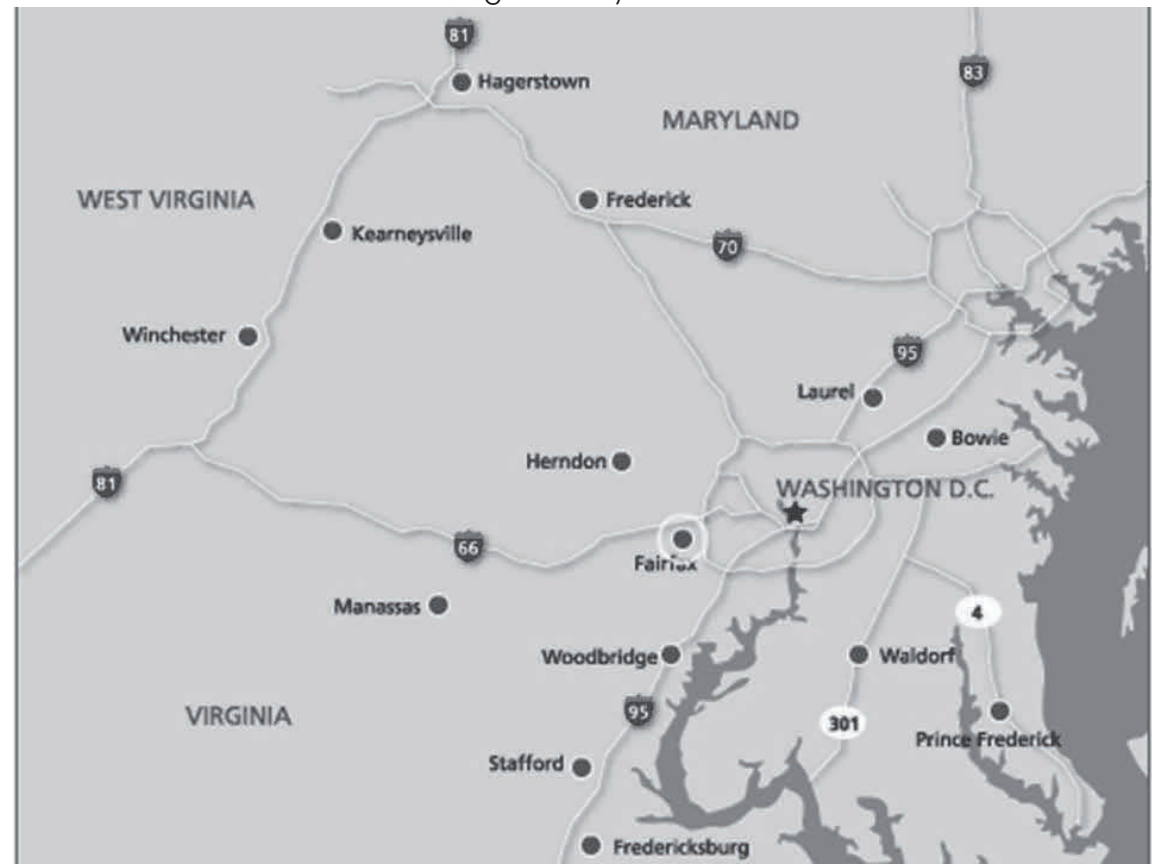

Forrás: U. S. General Services Administration, www.gsa.gov/teleworkmap

ségeken teszi lehetővé egyes munkafeladatok távmunkaházból történő ellátását, ami jelentős motivációt jelent a vállalatok számára (például a bérköltségek 30\%-kal, az ingatlanköltségek mintegy $50 \%$-kal is alacsonyabbak vidéken, mint egy nagyvárosban). Mivel a szellemi tevékenységek költsége elsősorban a bérből, ingatlanból és kommunikációs költségekből tevődik össze, a távmunka révén a vállalatok azonnali, 20-40\%-os költségcsökkenést realizálhatnak (Forgács 2008a, Forgács 2004).

A távmunka gazdasági előnyt jelenthet egy település számára is. A távmunkás foglalkoztatás során a béreken keresztül tőke és tudás áramolhat a régióba. A tőke a helyi vállalkozások bevételét növelheti, a tudás pedig javíthatja a helyben lakók elhelyezkedési és vállalkozási esélyeit. A térség így a közlekedés jelentős fejlesztése és ipari központ telepítése nélkül is jelentősen képes javítani gazdasági helyzetét. A távmunka által tehát az egész térség gazdasági és foglalkoztatási versenyképessége javulhat (Bagley 1994, Campbell 1995, Ernberg 1998, Gomez 1999, Whyte 1999).

Bagley $(1994,45)$.10 tanácsot ad a távmunkaházak sikeres megvalósításához és fenntartásához:

1. Világos, reális és konzisztens célokat kell megfogalmazni, amelyek a projekt megvalósítása során iránymutatást adhatnak. 
2. Mélységi helyzetelemzésre és agresszív marketingakcióra van szükség már a megvalósítási fázis elején.

3. A tervezésre és megvalósításra 12-18 hónapot kell szánni.

4. Célszerű hosszú távú pénzügyi terveket készíteni, javasolt 5-7 éves periódusban gondolkodni.

5. Időt kell szánni a helyszín kiválasztására. A helyszínnek összhangban kell lennie a megfogalmazott célokkal és a pénzügyi lehetőségekkel.

6. Tervezzünk zárt helyeket állandó munkáltatók számára.

7. Főállású helymenedzser álljon rendelkezésre az adminisztrációs, technikai feladatok kezelésére.

8. Több funkciót érdemes tervezni az objektumba a gazdasági fenntarthatóság céljából (például munkavégzés, oktatás).

9. Készítsünk információs és tréninganyagokat a távmunkavégzésről, hogy ezzel segítsük a munkavállalókat és a munkáltatókat.

10. Dokumentáljuk a távmunkaház tevékenységének minden elemét, hogy összehasonlítható legyen más távmunkaközpontokkal."

Arra a kérdésre, hogy a magyarországi távmunkaházakat hová érdemes telepíteni, olyan kutatások és felmérések ismeretében lehet választ adni, amelyek a potenciális tevékenységek sajátosságait (helyfüggetlenség, telephely-választási kritériumok, ágazat), a helyi munkaerő tulajdonságait (a munkaerőpiac nagysága, kor és nemek szerinti megoszlás, képzettség, nyelvtudás), az ingatlanpiacot (elegendő mennyiségű és nagyságú épület), a távközlési infrastruktúrát, a helyi gazdaság szerkezetét, a gazdaságfejlesztési politikát és ösztönzőrendszert térképezik fel. Ez alapján kialakítható akár egy országos távmunkaház-stratégia is, amely tudatosan támogatja a távmunkaházak létrehozását oly módon, hogy biztosítja a foglalkoztatás viszonylag homogén országos eloszlását az újonnan létrejövő munkahelyeknek a legrászorulóbb térségekbe való irányításával.

\section{Hajlandóság a távmunkaházak igénybevételére}

Bár Magyarországon a távmunka elterjedtsége igen alacsony százalékon áll, de „ha a távmunka és más atipikus formák jelentőségét helyesen akarjuk megítélni a régi iparágakban, akkor inkább a trendekre kell figyelni, mint a jelenlegi adatokra. (...) 1860-ban még kisebb lázadást váltott ki egy amerikai textilgyárban, hogy a tulajdonos bezárta a munkásokat, megakadályozandó, hogy ki-be járjanak a gyárban, és annyi időt töltsenek a munkában, amennyi nekik tetszik. Az ipari társadalomra jellemző gyári munka csak 1914-re teljesedett ki” (Szabó 2002, 203).

Egy 2008-as empirikus kutatásban a távmunkaház igénybevételét mértük 10 mélyinterjú segítségével, valamint 100, legalább 50 fős hazai vállalat megkérdezésével, amelyek a távmunkát valamilyen formában már alkalmazzák. Az interjúk értékeléséhez fontos megjegyezni, hogy Magyarországon 2007 őszén nyílt 
meg az első és azóta egyedüli távmunkaház Örkényben, azaz felhasználási célja és az általa nyújtott lehetőségek elsősorban csak elméleti szinten lehetnek ismertek a vállalatok számára, ennek megfelelően a megkérdezett vállalatok döntéshozói közül csupán 18\% halott már a távmunkaházakról.

$\mathrm{Az}$ alacsony ismertségre való tekintettel a vizsgálatot három lépcsőben folytattuk le. Elsőként azt vizsgáltuk, hogy milyen hajlandóság mutatkozik a távmunkaházakban való foglalkoztatásra érintetlen üzleti körülmények között. A távmunkaházak vidéki településekre gyakorolt kedvező gazdaságfejlesztési és foglalkoztatáspolitikai hatásai miatt azonban tovább vizsgáltuk a hajlandóságot, erre irányuló ösztönzők használatát feltételezve. A második fázisban a távmunkaházban való foglalkoztatás ingyenességét (tehát azt, hogy nincs irodabérleti díj), a harmadik fázisban pedig vissza nem térítendő támogatás lehívását feltételezve mértük a hajlandóságot.

A megkérdezett cégek mintegy 12\%-a tartja elképzelhetőnek változatlan üzleti feltételek mellett, hogy az újonnan felvenni tervezett munkavállalói közül néhányat távmunkaházból foglalkoztatna. Ez a viszonylag alacsony hajlandóság betudható az alacsony ismertségének is, amit alátámaszt az is, hogy a szolgáltatószektorban, ahol a legmagasabb a távmunkaházak ismertsége, a legmagasabb az aránya azoknak a cégeknek is (21\%), amelyek alkalmaznának távmunkaházban munkavállalót. A válaszadók további 7\%-a jelezte, hogy irodabérleti díj megfizetése nélkül nyitott lenne a távmunkaházak használatára. Vissza nem térítendő támogatás esetén a munkáltatók további $9 \%$-a lenne hajlandó távmunkaház igénybevételére. Összességében tehát a jelenlegi távmunkáltatók mintegy $28 \%$-a jelenti a potenciált a távmunkaházakban való foglalkoztatásra, megfelelő ösztönzőrendszer kialakítása esetén.

A távmunkaházakban való foglalkoztatásra nyitott vállalatok körében felmértük, hogy mely munkakörökben tartják lehetségesnek a foglalkoztatást. A vállalatok kétharmada adatrögzítői és adatfeldolgozói munkakörök esetében tartja elképzelhetőnek a foglalkoztatást, de a cégek több mint fele az adminisztratív feladatokat ellátó munkavállalókat és könyvelő kollégákat is alkalmazna távmunkaházakban. A vélemények jól tükrözik a hazai gyakorlat hiányát, a válaszok ugyanis teljes mértékben mellőzték a nemzetközi gyakorlatban jelentős felhasználási módot, a magasan képzett szakemberek számára a lakóhelyükhöz közeli munkahelyek létrehozását.

A távmunkaházban való foglalkoztatástól elzárkózó vállalatok esetében vizsgáltuk azt is, hogy milyen indokokkal utasítják el ezt a foglalkoztatási módot. A spontán kérdésre a válaszadók fele nem tudta megindokolni, hogy miért zárkózik el a távmunkaházban történő foglalkoztatástól, ami a távmunkaházak alacsony ismertségéből és a koncepció részleteinek ismeretlenségéből is adódhat. A támogatott válaszadás esetében szintén magas volt azoknak az aránya, akik nem tudták megindokolni az elzárkózás okát. Ebben az esetben a válaszadók egyharmada a kommunikáció nehézségét emelte ki, de nem sokkal kisebb arányban vélték úgy a megkérdezettek, hogy ez nem okozna költségmegtakarí- 
tást számukra. A válaszadók egyötöde szintén anyagi okokkal magyarázza az elzárkózást, úgy tartva, hogy drága lenne kialakítani a távmunkaházakat.

A hajlandóság mélyebb feltárására vonatkozóan azt is megkérdeztük a válaszadóktól, hogy ha kizárólag olyan szakembert találnának egy munkakör betöltésére, aki csak távmunkában hajlandó munkát vállalni, akkor a távmunka melyik formájában alkalmaznák. A válaszadók egyharmada (29\%) nyilatkozott úgy, hogy ilyen esetben más munkavállalót alkalmaznának. A cégek 13\%-a lenne nyitott ilyen esetben a távmunkaházban való foglalkoztatásra, míg az otthoni és mobil távmunkára mintegy kétötödük (39\% és 42\%).

Megkértük a válaszadókat arra is, ítéljék meg, hogy inkább az alacsony képzettségű szakemberek esetében, költségcsökkentés céljából reális-e a távmunkaházak terjedése, vagy inkább munkaerő-megtartási szándékkal a magasan kvalifikált emberek foglakoztatása növelheti-e a távmunkaházak elterjedtségét. A megkérdezettek nagyobb része vélte úgy, hogy a távmunkaházak terjedését inkább az alacsonyabb képzettségű munkaerő elhelyezése fogja generálni, de jelentős egyetértés mutatkozott a magas végzettséggel rendelkező munkavállalók elégedettségének növelése céljából létrehozott távmunkaházak terjedésével is.

Megkértük a válaszadókat arra is, hogy jósolják meg, hogyan fog változni az otthoni távmunkában, valamint a távmunkaházban foglalkoztatottak száma a jövőben. A válaszadóknak csak mintegy 6\%-a bízott a távmunka alkalmazásának ugrásszerü növekedésében, azonban a többség úgy vélte, hogy ha lassan is, de a távmunka elterjedtsége növekedni fog. Az otthoni távmunka lassú növekedését 75\%, a távmunkaházban végzett távmunka terjedését pedig 51\% gondolta reálisnak. Csupán a válaszadók 15-16\%-a szerint nem fog változni a távmunka elterjedtsége. A válaszadók nagyobb része gondolta úgy, hogy az otthoni távmunka szerepe fog inkább növekedni, mint a távmunkaházban történő távmunka szerepe.

\section{Jegyzetek}

1 A felsorolásban megtartom az eredeti angol elnevezéseket, mert a névhasonlóságok miatt a fordítás nehezen tudná visszaadni a valódi jelentéstartalmat.

2 Section 630(a) of Public Law 105-277 (Flexiplace Work Telecommuting Programs).

\section{Irodalom}

Ács Judit (2005): A globalizáció, az európai integráció hatásai és a régió perspektivaái. Kutatási fórum, Debrecen

Bagley, M. N., Mannering, J. S., Mokhtarian, P. L. (1994): Telecommuting Centers and Related Concepts: 
A Review of Practice. Institute of Transportation Studies, University of California, Davis Bergum, S. (2007): What happened to telework? The Journal of E-working, 1., 13-44.

Bihari Gábor (szerk.) (1999): Teleházak és távmunka Magyarországon. Teleház Kht., h. n.

Campbell, C. J. (1995): Community Technology Centers: Exploring a Tool for Rural Community Development. The Centre for Rural Massachusetts University of Massachusetts, Amherst

Clark, S. D. II (1998): The Decision to Telework: A Synthesized Model. Thirty-First Annual Hawaii International Conference on System Sciences, 1., 393-402.

Crang, M., Crang, P., May, J. (1999): Virtual Geographies: Bodies, Space and Relations. Routledge, London

Ernberg, J. (1998): Integrated rural development and universal access towards a framework for evaluation of multipurpose community telecentre. Conference at the University of Guelph, Guelph, Ontario, Canada, October $26 \& 27,1998$

Európai Bizottság (2002): Európai Távmunka Keretmegállapodás. Brüsszel

Forgács Tamás (2004): Távmunka és költségcsökkentés. In.: Szeli Katalin (szerk.) (2004): Kutatási Jelentés 29., BME-ITTK-Infonia Alapítvány-Infinit Műhely, 4-9.

Forgács Tamás (2006): Távmunka - híd város és vidék között. „CORK+10” konferenciakötet. Sapientia Erdélyi Magyar Tudományegyetem, Csíkszereda

Forgács Tamás (2008a): Távmunkaház: alternatíva a vidékfejlesztésben. A Falu. 2008, ősz

Forgács Tamás (2008b): Egy kistérségi távmunka-stratégia bemutatása. Tér és Társadalom. 2., 123-145.

Forman Balázs (2004): Regionális gazdaságtan. Tananyag

Gomez, R., Hunt, P. (1999): Telecentre evaluation. International Development Research Centre, Ottawa

Hodson, N. (1995): The Economics of Teleworking. Telecommute `95, Santa Clara California, 7-10 November 1995

Hoványi Gábor (2002): A menedzsment új horizontjai. Közgazdasági Szemle, 49., 251-264.

Hrubi László (2004): Új követelmények a területi gazdaság fejlesztésében. Pécs

Hrubi László (2005): Regionális Gazdaságtan. Tananyag. PTE KTK Regionális Politika és Gazdaságtan Doktori Iskola, Pécs

Illés Iván (2007): Regionális gazdaságtan. Területfejlesztés. Typotex Kiadó, Budapest

Jansen, A. (1995): Rural Development Through Diffusion of Information Technology. Scandinavian Journal of Information Systems, 1., 99-120.

Klein Sándor (2004): Vezetés-és szervezetpszichológia. 3. kiadás, Edge 2000, Budapest

Latchem, C., Walker, D. (eds.) (2001): Telecentres: Case studies and key issues. The Commonwealth of Learning, Vancouver

Lund, Mokhtarian (1994): Telecommuting and residential location: Theory and implications for commute travel in monocentric metropolis. Transportation Research Record. Issue: 1463., 10-14.

Magyar Információs Társadalom Éves Jelentés, 2006

Mokhtarian, P. L. (1991): Defining telecommuting. Transportation Research Record, vol. 1305., 273-281.

Obra, A. R., Cámara, S. B., Meléndez, A. P. (2002): The economic and organizational aspects of telecentres: the Spanish case. Technovation, 22., 785-798.

Rimler Judit (1999): A munka jövője. Közgazdasági Szemle, 46., 772-788.

Stanek, D. M., Mokhtarian, P. L. (1998): Developing models of preference for home-based and center-based telecommuting: Findings and forecasts. Technological Forecasting and Social Change, 1-2., 53-74.

Szabó Katalin (2002): Az információs technológiák szétterjedésének következményei a hagyományos szektorokban. Közgazdasági Szemle, 49., 193-211.

VÁTI Kht. (2003): A gazdasági térszerkezet vizsgálatát elősegito” új dimenziók, illetve az ezzel kapcsolatos módszerek kutatása. Kutatási összefoglaló, zárójelentés. Budapest

Vega, G. (ed.) (2003): Managing Teleworkers and Telecommuting Strategies. Greenwood Publishing Group

Whyte, A. (1999): Understanding the Role of Community Telecentres in Development. A Proposed Approach to Evaluation

WorldAtWork (2009): Telework Trendlines 2009. Washington 